well as say. Wood or copperplate engravings were important in seventeenth-century science, but such images were expensive to produce and limited in their information content. Now, practically every issue of a scientific journal is a cornucopia of high-bandwidth visual communication sometimes even in online video form. It is becoming easier to envisage present-day science communication without words than without images. It is disappointing then that many of the illustrations in The Scientific Literature are so murkily reproduced. Maybe it is easier for humanists to say that visual communication is important than for them and their publishers to act as if it is.

Steven Shapin is in the Department of the History of Science, Harvard University, 1 Oxford Street, Cambridge, Massachusetts 02138, USA.

\title{
Material metaphors
}

\section{Origins and Revolutions: Human Identity \\ in Earliest Prehistory \\ by Clive Gamble \\ Cambridge University Press: 2007. 362 pp. \\ \$80, £45 (hbk); \$27.99, £15 (pbk)}

\section{Robert N. Proctor}

Research into human origins can be thought of as a kind of identity quest. We want to know how 'they' became 'us', which raises all kinds of questions about what it means to be human. To stand upright? To paint the walls of caves or to fashion beads from bone? Or to plant the land and build cities with slave labour? Or perhaps to engage in none of the above, but simply to have that capacity?

Questions such as these do not have obvious answers, nor are they really even empirical. Evolution stretches out the process of anthropogenesis. Once we jettison teleology and discontinuity, it doesn't mean much to say when hominins became 'truly human', any more than to say when aardvarks became truly aardvark. Nor can it even mean much to talk about the 'earliest' humans, or prehistory, as everything will depend on what we want to identify as the important transitions.

Upright posture, for example, appeared by about 4 million years ago, but tool making must be much older, albeit invisible as a result of accidents of preservation. The oldest known wooden tools, the famous spears from Schöningen in Germany, date from only 400,000 years ago. Symbolic burial and bead making are younger still, perhaps by an order of magnitude.

Clive Gamble's new book, Origins and Revolutions, challenges our current obsession with language and farming as the two principal 'big breaks' in deep antiquity, dating from around 40,000 and 10,000 years ago, respectively. His intention is to avoid all talk of origins, exploring instead what he calls the "material basis of human identity", by which he means how artefacts as extensions of the human body acquire a symbolic force of their own.

He divides the material world into "instru- ments" and "containers". Here instruments include all edges, blades and points, as well as pestles, ploughs, drills, axes, brushes, writing implements and wheels. Containers include anything that houses or envelops, whether in the form of bowls, barns, bags, caves, clothes, moulds, masks or tombs. Gamble's point is that both are extensions of the human body: instruments extend our limbs; containers extend our trunk. Instruments generally inscribe; containers are more often inscribed upon.

Classifying material culture in this way

singular point of origin, whether 40,000 years ago with the 'human revolution' or at any other magical moment.

Palaeoanthropology has become an exciting field in recent years, partly because some really big questions remain wonderfully unanswered. No one really knows whether Neanderthals could speak or think like us, for example, or what it might have been like to live among our Homo erectus next-of-kin or the newly discovered Homo floresiensis. In the 1960s and 1970s, language, art and symbolism were projected onto ever-older hominin fossils. Now the trend is to (re-) dehumanize early palaeolithic hominins - hence the darkening of the whites of their eyes in recent museum displays.

Gamble's refocus on instruments and containers is a refreshing break from archaeological convention. But how far back can we go before such proxies for the hominin body cease to have symbolic force? Birds' nests are containers, so when do the hominin counterparts start to signify something more to their makers? When do the instruments of early hominins start to serve as material metaphors? How would we ever know whether, say, the invention of symbolism wasn't rather sudden, even from a geological point of view? How would we ever know whether a light went on in some hominin head (or gene), causing language to spring into being?

Gamble shows that the rate of invention grows slowly over the long haul of human evolution, and reminds us that absence of evidence is not evidence of absence. But how long should we search the Middle Palaeolithic for painted caves or sculpted figurines before concluding that none was ever done, and not for lack of interest, but for lack of capacity? For many years, geologists were reluctant to recognize catastrophes, postulating 'missing strata' to account for apparent jumps. The

allows Gamble to question the novelty of both the Neolithic and the Upper Palaeolithic transitions. He argues instead for a more gradual shift over millions of years of hominin evolution, from a life centred around instruments to a life more prominently incorporating containers. Farming, then, is not such a radical innovation. There is no 'sapient paradox' - Colin Renfrew's puzzle over why it took so long to discover agriculture and the virtues of a sedentary life. Symbolism was not suddenly invented when modern humans decided to quit Africa and start painting in southern France. (Paradox seekers might well wonder why the 'modern mind' seems to appear 100,000 years after the 'modern body'.) Instruments and containers always reference the human body, and in this sense carry symbolic force. This means that symbolism does not necessarily have a rehabilitation of catastrophes over the past few decades owes much to a renewed appreciation that absence of evidence can be evidence of an absence. I think it is fair to ask whether the situation might not be similar for palaeoanthropology.

Origins and Revolutions is an effervescent read that skillfully challenges many of the sacred cows of archaeology. It is rich and deep in the philosophical acumen and attention to social theory for which Gamble is known. He also writes with an admirable sense of humour and irony; he knows how to join humanistic flair with empirical rigour at the dig.

I think he is right that our bodies are a kind of social technology, and that artefacts should be regarded as embodied metaphors. The question then arises of how to understand changes in interactions between artefacts, with 
the invention of compound tools. Following Gamble, compound artefacts might well be thought of as material metaphors for language. They help make metaphors, and in this sense language, possible.

Compound artefacts open up a near-infinite recombination of uses, just as language allows a near-infinite recombination of words. If there's any truth to the idea that language and composite tools arose together, surely we can ask how big or how sudden must such a change have been to constitute a revolution. As Gam- ble himself asks, when challenging stone-flaking taxonomies: "At what moment does eating produce the core of an apple"?

Robert N. Proctor is professor of the history of science at Stanford University, Stanford, California 94305, USA.

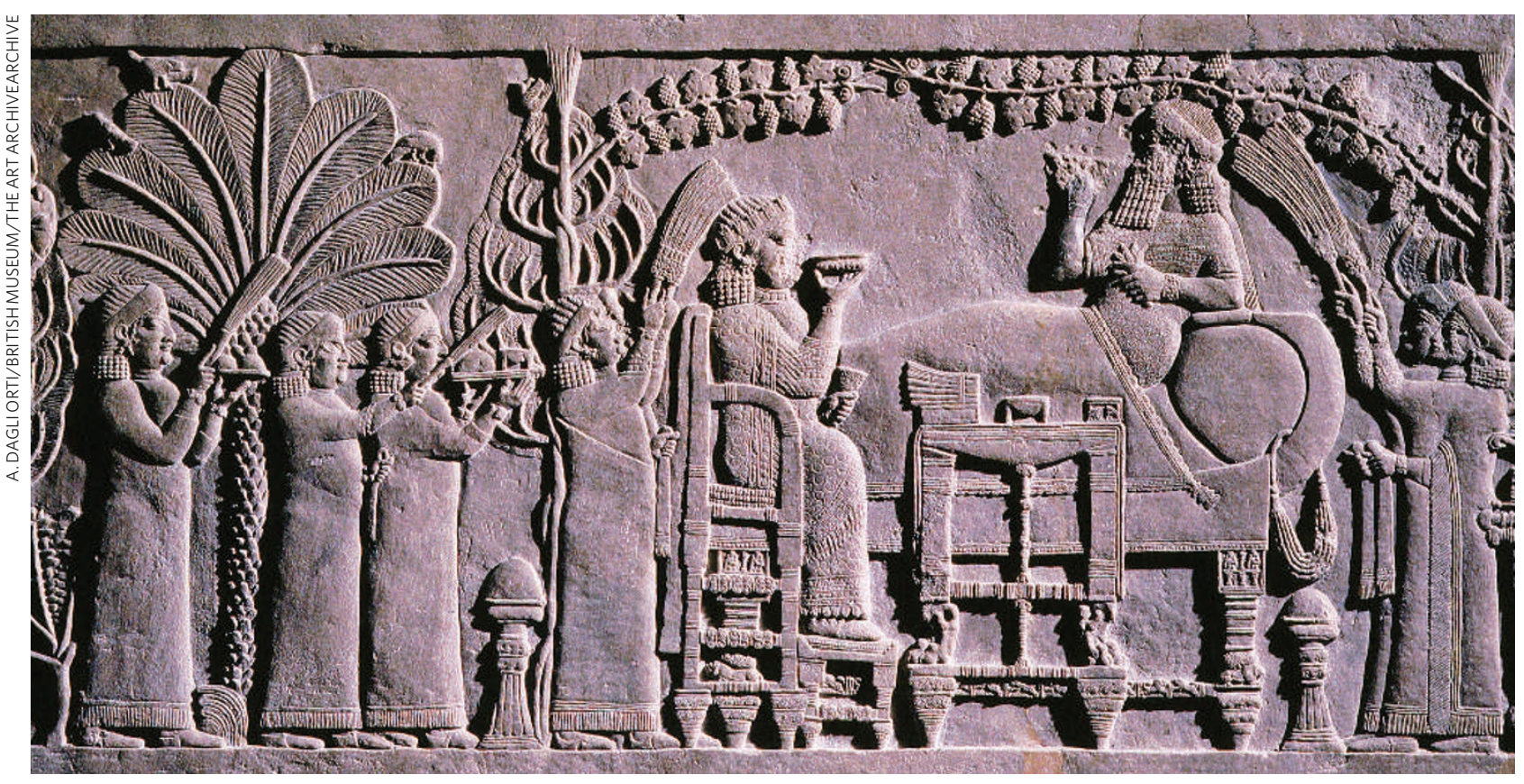

\section{Left to digest}

\section{In ancient art, banqueters always recline on their left side - perhaps to aid digestion.}

Paolo Mazzarello and Maurizio Harari

The élite of most advanced ancient

Mediterranean societies partook of banquets lying down. We know this from iconographic records dating back to the seventh century BC. Some scholars assume that the custom was widespread in the originally nomadic tribes that finally settled in Syria or Iran, befitting their modest tent furnishings. But the social prestige that soon became associated with reclining at a banquet might owe more to the preciousness of the beds of the rich, as suggested by the outpouring of the biblical prophet Amos (around $750 \mathrm{BC}$ ), against those used by the Samarians: "Lying upon beds of ivory, stretched comfortably on their couches, they eat lambs taken from the flock." (Bible, Amos 6:4-7).

So it's not surprising that one of the oldest images of a reclining banquet is a royal one: the famous bas-relief of King Assurbanipal of Assyria lying on his left side while his wife sits on the throne (pictured). This form of aristocratic banquet was widespread in the seventh century BC in Greece - the poet Archilochus wrote, "leaning on my lance I drink (wine)" - and among the Etruscans, who traded with the Greeks. It came to span the entire Mediterranean Greek and Roman civilizations.

Art historians have often noted that banqueters almost always appear to be reclining on their left sides. The usual explanation is that lying on the left leaves the right hand free to hold the dining vessels. But in funereal art there is good documentation of presumptive left-handed banqueters also reclining to the left. JeanMarie Dentzer in his book Le motif due banquet couché dans le Proche-Orient et le monde Grec du VIle au IVe siècle avant J.-C.

(Ecole Francais, Rome, 1982) has compiled an extensive inventory of the banquet couché between the seventh and fourth centuries BC. Of the more than 700 illustrations, including at least a dozen banqueters holding pots in their left hand, not one is lying on their right side.

One explanation could lie in the anatomy of the stomach and in the digestive mechanism. The stomach has an irregular shape that curves upon itself. Its rounded base is turned to the left. There are two openings: one at the top where food enters from the oesophagus and one at the base, the pyloric orifice, from which part-digested food exits.

Eating lying down increases abdominal pressure and thus promotes gastrooesophageal reflux, in which the acid stomach contents are forced back up the oesophagus, causing the unpleasant sensation known as heartburn. When lying on the left, the chewed food has room to expand because the curvature of the stomach is enhanced in that position. The lesser curvature on the right side of the stomach gives little space for food to resist the increased abdominal pressure and so lying on the right will soon cause reflux.

For the ancient Mediterranean civilizations, the evening meal lasted hours, and involved a lot of eating and drinking. Lying on the left would not just have reduced the risk of reflux, it would also have provided space for the large amounts of food the revellers were required to eat.

Paolo Mazzarello is professor of humanities and the history of medicine in the Department of Experimental Medicine, Maurizio Harari is professor of Etruscology in the Department of Classics, University of Pavia, 27100 Pavia, Italy. 